\title{
Facial nerve ganglioneuroblastoma in a feline leukemia virus-positive cat
}

\author{
Paula Reis Pereira ${ }^{1^{*}}$ Nelson Junior Tagliari ${ }^{2}$ Ronaldo Viana Leite-Filho ${ }^{1}$ \\ Gabriela da Cruz Schaefer ${ }^{2}$ Fernanda Vieira Amorim da Costa ${ }^{3}$ Saulo Petinatti Pavarini ${ }^{1}$
}

${ }^{1}$ Setor de Patologia Veterinária, Faculdade de Veterinária, Universidade Federal do Rio Grande do Sul (UFRGS), Av. Bento Gonçalves, 9090, Prédio 42505, 91540-000, Porto Alegre, RS, Brasil. E-mail: paula.rpereira@hotmail.com. *Corresponding author.

${ }^{2}$ Hospital Veterinário de Pequenos Animais, Faculdade de Veterinária, Universidade Federal do Rio Grande do Sul (UFRGS), Porto Alegre, RS, Brasil. ${ }^{3}$ Departamento de Medicina Animal, Universidade Federal do Rio Grande do Sul (UFRGS), Porto Alegre, RS, Brasil.

ABSTRACT: Neuroblastic tumors can originate from the central neuraxis, olfactory epithelium, adrenal medullary region or autonomous system. Ganglioneuroblastoma are a type of neuroblastic tumor, with very few case descriptions in animals. Diagnosis of facial nerve ganglioneuroblastoma was made in a feline leukemia virus-positive 11-month-old cat. The cat had hyporexia, left head tilt, depressed mental state, horizontal nystagmus, inability to retract the pinched left lip, anisocoria, ptosis, and absence of the menace reflex. Gross necropsy showed a mass at the left facial nerve root region. Histological examination of this mass showed neoplastic proliferation of neuroblasts arranged in a cohesive pattern and mature ganglion cells. Ganglion cells were positive for neurofilament, neuron-specific enolase, S100, and glial fibrillary acidic protein by immunohistochemistry, while neuroblasts were positive for vimentin, S100, neuron-specific enolase and feline leukemia virus. Key words: neuronal neoplasm, cranial nerve VII, immunohistochemistry, feline leukemia virus.

Ganglioneuroblastoma de nervo facial em um gato infectado pelo vírus da leucemia felina

RESUMO: Tumores neuroblásticos podem se originar do neuraxis central, do epitélio olfativo, região medular da adrenal ou do sistema autônomo. O ganglioneuroblastoma é um tipo desses tumores, com raras descrições em animais. O diagnóstico de ganglioneuroblastoma de nervo facial foi feito em um gato de 11 meses de idade, sorologicamente positivo para o vírus da leucemia felina. O gato tinha hiporexia, inclinação de cabeça para o lado esquerdo, estado mental deprimido, nistagmo horizontal, incapacidade em retrair o lábio esquerdo quando pinçado, anisocoria, ptose e ausência do reflexo de ameaça. Na necropsia visualizou-se uma massa na região da raiz do nervo facial esquerdo. $O$ exame histológico mostrou proliferação neoplásica de neuroblastos arranjados de maneira coesa, e células ganglionares maduras. As células ganglionares foram imunorreativas na imuno-histoquímica para neurofilamento, enolase neurônio especifica, S-100 e proteína ácida glial fibrilar. Enquanto os neuroblastos foram positivos para vimentina, S-100, enolase neurônio especifica e virus da leucemia felina. Palavras-chave: neoplasia neuronal, VII nervo craniano, imuno-histoquímica, vírus da leucemia felina.

Neuronal neoplasms are rare in 2002) Neuroblastoma ganglioneuroblastoma ganglioneuroma are neural tumors with varying maturity levels derived from neural crest cells that form the sympathetic nervous system. These cells may remain as undifferentiated precursor cells (neuroblasts) or can mature, forming ganglion and Schwann cells (JOSHI, 2000). Olfactory and oral mucosa ganglioneuroblastomas have been described in dogs (MATTIX et al., 1994; NAKAMURA et al., 2004). In cats, they have been reported in the plantar region of the pelvic limb and spinal cord, extending from the fifth to the seventh lumbar vertebrae (SPUGNINI et al., 2008; RIVARD et al., 2016).

Feline leukemia virus (FeLV) is a retrovirus with global distribution. FeLV infection is associated with bone marrow suppression, immune suppression, immune-mediated diseases and other disorders, including reproductive diseases and neuropathies (HARTMANN, 2006). Moreover, FeLV has oncogenic potential and causes various tumors in cats, such as lymphoma, leukemia, osteochondroma and olfactory neuroblastoma (HARTMANN, 2006). This report describes a case of facial nerve ganglioneuroblastoma in a FeLV-positive 11-monthold cat and highlights the clinical, pathological and immunohistochemical features.

An 11-month-old neutered male crossbred cat was referred to a veterinary clinic hospital. The cat had hyporexia, left head tilt, inability to retract the pinched left lip, horizontal nystagmus, anisocoria, and depressed mental state. These symptoms had 
developed over 30 days. In the neuro-ophthalmologic assessment, the left ocular globe had nonresponsive mydriasis, loss of direct pupillary light reflex, ptosis, corneal ulceration, and absence of the menace reflex. In addition, leukocytosis (22.300; reference range (RR): $\left.5.000-19.500 \mathrm{~mm}^{-3}\right)$, neutrophilia (18.286, RR: $2.500-12.500 \mathrm{~mm}^{-3}$ ) and monocytosis (2.007, RR: $0-850 \mathrm{~mm}^{-3}$ ) were observed. Samples were negative for FIV (feline immunodeficiency virus) specific antibodies but positive for FeLV (SNAP FIV Antibody/ FeLV Antigen Combo, IDEXX Laboratories, Westbrook, ME, USA). No alteration of the tympanic bullae was observed by radiographic examination. The cat was initially treated with topical administration of ophthalmic atropine $1 \%$ and tobramycin, with review and further tests the next day. The owner returned 10 days later, complaining that the cat seemed to have trouble getting up on all four legs and maintaining its balance; after taking a few steps, the cat abruptly listed to one side, tipped over, became suddenly unable to walk and remained in constant lateral recumbency.

The cat underwent a routine necropsy examination after it died. There was a mass located at the entrance of the internal auditory meatus at the root of the left facial nerve. This mass exhibited a whitish coloration, a firm consistency, and a solid cut surface and measured $1.0 \mathrm{~cm}$ in diameter (Figure 1A). Cerebellar and caudal portions of the brain stem were caudally displaced (cerebellar and brainstem herniation) (Figure $1 \mathrm{~A}$ inset). Fragments of all organs were fixed in $10 \%$ formalin, and tissues were processed routinely and embedded in paraffin. Three micrometer sections of the paraffin blocks were made and stained with hematoxylin and eosin. Histologic examination of the mass revealed neoplastic proliferation infiltrating the adjacent cerebellar tissue; the mass was composed of a mixture of neuroblasts arranged in a cohesive pattern and numerous cells with neuronal features (ganglion cells) interspersed with delicate stroma. Neuroblasts were round to oval, with a distinct eosinophilic cytoplasm that sometimes exhibited vacuoles, round hyperchromatic nuclei with finely stippled chromatin and prominent nucleoli. Moderate anisocytosis and anisokaryosis and occasional binucleate cells were seen. The mitotic rate was identified as six cells per high power field (Figure 1B).

Serial sections were subjected to immunohistochemistry (IHC); the protocols are summarized in table 1. Immunohistochemical analysis of neurofilament (Figure 1C), neuron-specific enolase (NSE) (Figure 1D), glial fibrillary acidic protein (GFAP) (1D inset) and S100 (Figure 1E) showed a positive reaction in the cytoplasm of ganglion cells, extending to their cellular processes. Neuroblasts were positive for vimentin and S100 (Figure 1E), specifically in the nucleus and cell membrane, and exhibited discrete positive staining for NSE in the cytoplasm (Figure 1D). No staining was observed for cytokeratin, T lymphocytes (CD3) or B lymphocytes (CD79) in neoplastic cells. In addition, the neuroblasts were positive for FeLV (Figure 1F).

Diagnosis of facial nerve ganglioneuroblastoma related to FeLV infection in the cat described in this paper was based on clinical, pathological, and immunohistochemical features. The inability of the cat to retract the pinched left lip and the absence of the menace reflex in the left eye are directly related to the primary neoplasm of the left facial nerve. Similarly, the observed corneal ulcer is considered a common sequela of facial nerve injury (KORNEGAY \& LORENZ, 2006). The pronounced head tilt to the left side, horizontal nystagmus, depressed mental status, and constant lateral recumbency are closely associated with central vestibular syndrome (TROXEL et al., 2005). Disorders that cause malfunction of the vestibular system can range dramatically in severity, as observed in the case presented here. This may be due to the pressure applied by the tumor to the nervous tissue. The combination of ptosis, ipsilateral pupillary dilation, and lack of response to light is a manifestation of oculomotor nerve disorder (SLATTER, 2005). Ptosis can also occur in cases of trigeminal nerve damage (SLATTER, 2005). These changes in this cat may have been related to increased intracranial pressure on the brainstem and the cerebral cortex, in addition to herniation of the cerebellum and brainstem (CARLOTTI et al., 1998).

Histologically, ganglioneuroblastoma is composed of neuroblasts (undifferentiated precursor cells) and ganglion (differentiated mature cells), as observed in this case, and the presence of these cell types is a diagnostic criterion for ganglioneuroblastoma (MATTIX et al., 1994). The diagnosis of neuropathologies has benefited greatly from IHC; however, there is a high degree of variability in immunoreactive patterns (KOESTNER \& HIGGINS, 2002; RIVARD et al., 2016). In animals, the ganglion cells of ganglioneuroma and ganglioneuroblastoma are strongly immunoreactive for neurofilament (KOESTNER \& HIGGINS, 2002). In addition to an immunoreaction to neurofilament, ganglion cells are positive for NSE, S100 and GFAP, and neuroblasts are positive for vimentin, NSE and S100. NAKAMURA et al. (2004) reported that ganglion cells were immunoreactive for NSE, neurofilament and S100, while the immature cells were immunoreactive for 


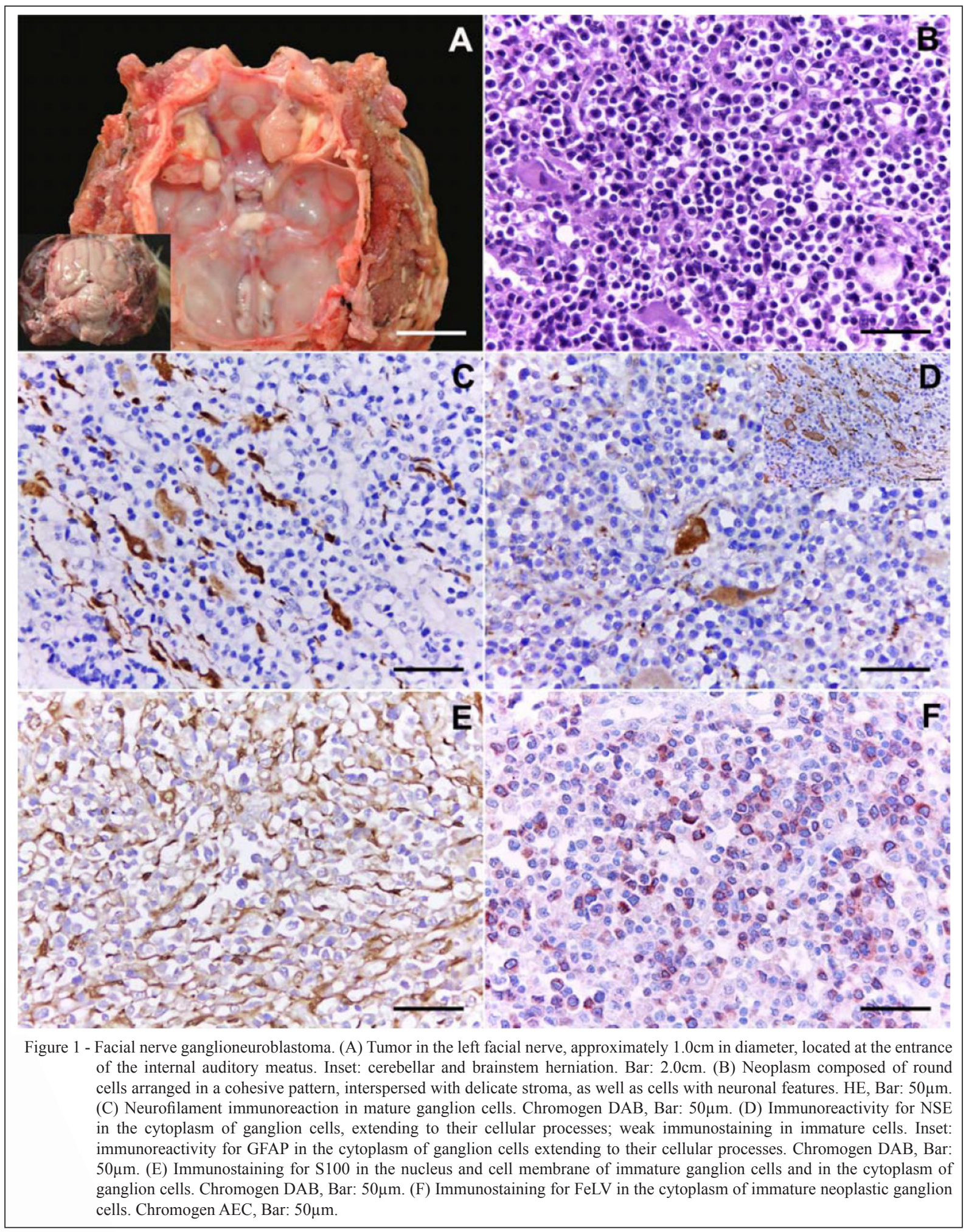

vimentin, GFAP and S100. This current report had very similar immunoreactivity to that described by
NAKAMURA et al. (2004), with the addition of GFAP immunoreactivity in ganglion cells.

Ciência Rural, v.47, n.5, 2017. 
Table 1 - Antibodies and immunohistochemistry procedures.

\begin{tabular}{|c|c|c|c|c|}
\hline Antibody & Antigen retrieval & Dilution & $\begin{array}{l}\text { Detection } \\
\text { method }\end{array}$ & Chromogen \\
\hline Mouse anticytokeratin AE1/ AE3 & $3 \mathrm{~min} / 125^{\circ} \mathrm{C}$, Citrate buffer $\mathrm{pH} 6.0$ & $1: 80$ & LSAB-HRP & $\mathrm{DAB}$ \\
\hline Mouse antifeline leukemia virus (gp 70) & $40 \mathrm{~min} / 100^{\circ} \mathrm{C}$, Tris EDTA buffer $\mathrm{pH} 9.0$ & $1: 500$ & MACH 4 & $\mathrm{AEC}$ \\
\hline Mouse antihuman CD 79 & $20 \mathrm{~min} / 96^{\circ} \mathrm{C}$, Tris EDTA buffer $\mathrm{pH} 9.0$ & $1: 100$ & $\mathrm{MACH} 4$ & DAB \\
\hline Mouse anti-NSE & $40 \mathrm{~min} / 96^{\circ} \mathrm{C}$, Citrate buffer $\mathrm{pH} 6.0$ & $1: 200$ & LSAB-HRP & $\mathrm{DAB}$ \\
\hline Mouse anti-vimentin & $3 \mathrm{~min} / 125^{\circ} \mathrm{C}$, Citrate buffer $\mathrm{pH} 6.0$ & $1: 200$ & LSAB-HRP & DAB \\
\hline Polyclonal rabbit antihuman $\mathrm{CD} 3$ & $15 \mathrm{~min} /$ protease XIV & $1: 500$ & MACH 4 & $\mathrm{AEC}$ \\
\hline Rabbit anti-GFAP & $10 \mathrm{~min} / 100^{\circ} \mathrm{C}$, Tris EDTA buffer $\mathrm{pH} 9.0$ & $1: 500$ & LSAB-HRP & DAB \\
\hline Rabbit anti-neurofilament & $10 \mathrm{~min} / 37^{\circ} \mathrm{C}$, Trypsin and citrate buffer $\mathrm{pH} 6.0$ & $1: 500$ & LSAB-HRP & $\mathrm{DAB}$ \\
\hline Rabbit anti-S100 & $20 \mathrm{~min} / 100^{\circ} \mathrm{C}$, Citrate buffer $\mathrm{pH} 6.0$ & $1: 200$ & LSAB-HRP & DAB \\
\hline
\end{tabular}

LSAB - HRP = streptavidin biotin peroxidase $($ Dako); MACH $4=$ Universal HRP Polymer (Biocare); AEC = 3-amino-9-ethylcarbazole $($ Dako); DAB = 3,3'Diaminobenzidine (Dako); NSE = neuron-specific enolase; GFAP = glial fibrillary acidic protein.

Although these types of tumors are extremely rare, diagnostic criteria and differential diagnosis are necessary, as is specifying the type of ganglion cell neoplasm (JOSHI, 2000; RIVARD et al., 2016). If the mass contains mainly neuroblasts (immature ganglion cells), it is referred to as neuroblastoma; however, when the mass is composed entirely of mature ganglion cells and other mature tissue, it is considered a ganglioneuroma, while ganglioneuroblastomas have both immature and mature cells (JOSHI, 2000).

FeLV is recognized as an oncogenic retrovirus, and it has been identified as the causative agent of various neoplasms in cats (HARTMANN, 2006). SCHRENZEL et al. (1990) identified viral particles in three cats with olfactory neuroblastoma that, through IHC, demonstrated an immunoreaction in the cytoplasm of neoplastic cells for FeLV, similar to what was observed in our case. The mechanism by which the virus causes neuroblastoma development has not yet been elucidated (SCHRENZEL et al., 1990). However, the detection of viral particles in neoplastic cells indicated a possible role of FeLV in the origin of these tumors.

\section{BIOETHICS AND BIOSSECURITY COMMITTEE APPROVAL}

We authors of the article entitled "Facial nerve ganglioneuroblastoma in a feline leukemia virus-positive cat" declared, for all due purposes, the project that gave rise to the present data of the same has not been submitted for evaluation to the Ethics Committee of the Universidade Federal do Rio Grande do Sul (UFRGS), but we are aware of the content of the Brazilian resolutions of the Conselho Nacional de Controle de Experimentação Animal (CONCEA) <http://www.mct.gov.br/ index.php/content/view/310553.html > if it involves animals.

Thus, the authors assume full responsibility for the presented data and are available for possible questions, should they be required by the competent authorities.

\section{REFERENCES}

CARLOTTI JR, C. G et al. Hipertensão intracraniana. In: SIMPÓSIO: MEDICINA INTENSIVA II. Tópicos selecionados, 1998, Ribeirão Preto, SP. Ribeirão Preto: Universidade de São Paulo. v.31, p.552-562.

HARTMANN, K. Feline leukemia virus infection. In: GREENE, C. E. Infectious diseases of the dog and cat. 3.ed. St. Louis: Elsevier, 2006. Cap.13, p.105-131.

JOSHI, V. V. Peripheral neuroblastic tumors: pathologic classification based on recommendations of international neuroblastoma pathology committee (modification of Shimada classification). Pediatric and Developmental Pathology, v.3, p.184-199, 2000. Available from: <http://sci-hub.cc/10.1007/ s100240050024>. Accessed: Apr. 20, 2015. doi: 10.1007/ s100249910024.

KOESTNER, A.; HIGGINS, R. J. Tumors of the nervous system. In: MEUTEN, D. J. Tumors in domestic animals. 4. ed. Ames, Iowa: Iowa State, 2002. Cap.14, p.712-716.

KORNEGAY, J. N.; LORENZ, M. D. Neurologia veterinária. São Paulo, Manole, 2006. 480p.

MATTIX, M. E. et al. Olfactory ganglioneuroblastoma in a dog: a light, ultrastructural and immunohistochemical study. Veterinary Pathology, v.31, p.262-265, 1994. Available from: <http://vet. 
sagepub.com/content/31/2/262.full.pdf>. Accessed: Apr. 28, 2015. doi: $10.1177 / 030098589403100219$.

NAKAMURA, K. et al. Canine ganglioneuroblastoma in the oral mucosa. Journal Comparative Pathology, v.130, p.205-208, 2004. Available from: <http://dx.doi.org/10.1016/j.jcpa.2003.09.002>. Accessed: Apr. 20, 2015. doi: 10.1016/j.jcpa.2003.09.002.

RIVARD, B. C. etal. Intraparenchymal spinal cord ganglioneuroblastoma originating from the peripheral sympathetic nervous system in a cat. Journal of Veterinary Internal Medicine, v.30, p.647-652, 2016. Available from: <http://onlinelibrary.wiley.com/doi/10.1111/ jvim.13835/pdf $>$. Accessed: Jul. 05, 2016. doi: 10.1111/jvim. 13835.

SCHRENZEL, M. D. et al. Type C retroviral expression. In spontaneous feline olfactory neuroblastomas. Acta neuropathologica, v.80, p.547-553, 1990. Available from: <http://link.springer.com/ article/10.1007\%2FBF00294617>. Accessed: Apr. 19, 2016. doi: 10.1007/BF00294617.

SLATTER, D. Fundamento de oftalmologia veterinária. 3. ed. São Paulo: Roca, 2005. 712p.

SPUGNINI, E. P. et al. Ganglioneuroblastoma in a cat: A rare neoplasm treated with electrochemotherapy. Veterinary Journal, v.178, p.289291, 2008. Available from: <http://fulltext.study/download/2465680. pdf>. Accessed: Apr. 19, 2016. doi:10.1016/j.tvj1.2007.08.014.

TROXEL, M. T. et al. Signs of neurologic dysfunction in dogs with central versus peripheral vestibular disease. In: DE LAHUNTA, A.; GLASS, E. Veterinary neuroanatomy and clinical neurology. 3.ed. Missouri: Elsevier, 2005. Cap.12, p.327. 